\title{
PENDIDIKAN LINGKUNGAN HIDUP DENGAN METODE OUTBOUND UNTUK ANAK USIA DINI : KAJIAN PUSTAKA
}

\author{
Joice Noviana Pelima \\ Email: joicenoviana.ps@gmail.com \\ Program Studi Agribisnis Universitas Kristen Tentena
}

\begin{abstract}
Abstrak
Proses pembelajaran pendidikan lingkungan hidup merupakan salah satu mata pelajaran penting bagi pembangunan karakter cinta lingkungan sejak anak usia dini. Dunia anak adalah dunia bermain maka model pembelajaran yang dapat mendukung pembentukan karakter cinta lingkungan adalah pembelajaran luar kelas dengan metode outbound. Melalui metode bound siswa memperoleh pengalaman belajar tentang alam sekitarnya sambil melakukan aktivitas motorik yang menyenangkan. Guru berperan sebagai fasilitator yang mendampingi siswa untuk mengarahkan aktivitas siswa dalam kegiatan outbound sehingga sasaran dan tujuan pembelajaran pendidikan lingkungan hidup tercapai.

Kata Kunci: Lingkungan Hidup, Outbound, Anak Usia Dini
\end{abstract}

\begin{abstract}
The learning process of environmental education is one of the important subjects for the development of character to care the environment since early childhood. Child's world is the world of playing so that the learning model that can support the development of the character is learning outside the room with outbound methods. Through the method students can gain learning experience about the natural surroundings while they can perform interesting motor movement. Teachers act as facilitators who assist students to direct the activities of students in outbound activities so that the goals and objectives of environmental education learning can be achieved.

Keywords: Environment, outbound, Early Childhood
\end{abstract}




\section{PENDAHULUAN}

Kesadaran masyarakat dunia terhadap masalah lingkungan hidup di awali dengan dibentuknya sebuah lembaga yang menangani masalah lingkungan hidup, yaitu United Nations Enviromental (UNEP) pada konferensi Lingkungan Hidup Dunia tahun 1972 di Stockholm. Selanjutnya PBB secara aktif menyelenggarakan beberapa konferensi khusus membahas tentang pemeliharaan lingkungan hidup dunia.

Di Indonesia pada awalnya penyelenggaraan Pendidikan Lingkungan Hidup (PLH) dilakukan oleh Institut Keguruan Ilmu Pendidikan (IKIP) Jakarta pada tahun 1975. Pada tahun 1977/1978 rintisan Garis-garis Besar Program Pengajaran Lingkungan Hidup diujicobakan di 15 Sekolah Dasar Jakarta. Pada tahun 1979 di bawah koordinasi Kantor Menteri Negara Pengawasan Pembangunan dan Lingkungan Hidup (Meneg PPLH) dibentuk Pusat Studi Lingkungan (PSL) di berbagai perguruan tinggi negeri dan swasta, dimana pendidikan Analisis Mengenai Dampak Lingkungan (AMDAL mulai dikembangkan). Sampai tahun 2010, jumlah PSL yang menjadi Anggota Badan Koordinasi Pusat Studi Lingkungan (BKPSL) telah berkembang menjadi 101 PSL.
Direktorat Jenderal Pendidikan Dasar dan Menengah Departeman Pendidikan Nasional (Ditjen Dikdasmen Depdiknas), menetapkan bahwa penyampaian mata ajar tentang kependudukan dan lingkungan hidup secara integratif dituangkan dalam kurikulum tahun 1984 dengan memasukan materi kependudukan dan lingkungan hidup ke dalam semua mata pelajaran pada tingkat menengah umum dan kejuruan. Tahun 1989/1990 hingga 2007, Ditjen Dikdasmen Depdiknas, melalui Proyek Pendidikan Kependudukan dan Lingkungan Hidup (PKLH) melaksanakan program Pendidikan Kependudukan dan Lingkungan Hidup; sedangkan Sekolah Berbudaya Lingkungan (SBL) mulai dikembangkan pada tahun 2003 di 120 sekolah. Sampai dengan berakhirnya tahun 2007, proyek PKLH telah berhasil mengembangkan SBL di 470 sekolah, 4 Lembaga Penjamin Mutu (LPMP) dan 2 Pusat Pengembangan Penataran Guru (PPPG).

Salah satu tujuan pendidikan lingkungan hidup adalah membentukan karakter cinta lingkungan. Pembentukan karakter ini idealnya dilakukan sejak usia dini. maka pendidikan lingkungan hidup sangat tepat jika diintegrasikan dalam kurikulum pendidikan anak usia dini karena 
usia dini adalah waktu yang tepat untuk menanamkan kecintaan anak terhadap lingkungan hidupnya.

Pendidikan pada anak usia dini pada dasarnya meliputi seluruh upaya dan tindakan yang dilakukan oleh pendidik dan orang tua dalam proses perawatan, pengasuhan dan pendidikan pada anak dengan menciptakan aura dan lingkungan dimana anak dapat mengeksplorasi pengalaman yang memberikan kesempatan kepadanya untuk mengetahui dan memahami pengalaman belajar yang diperolehnya dari lingkungan, melalui cara mengamati, meniru dan bereksperimen yang berlangsung secara berulang - ulang dan melibatkan seluruh potensi dan kecerdasan anak. Oleh karena anak merupakan pribadi yang unik dan melewati berbagai suasana, hendaklah memperhatikan keunikan anak anak dan disesuaikan dengan tahap perkembangan kepribadian anak (Sujiono, 2009). Sesuai tahap perkembangan anak usia dini maka sangat penting memberi ruang untuk memperoleh pengalaman belajar tentang lingkungan hidup secara langsung melalui aktivitas di luar kelas yang dirumuskan secara sistimatis dalam konsep pembelajaran di luar kelas

Lahirnya konsep pendidikan di alam terbuka adalah manifestasi dari pendidikan di luar ruangan. Alam sebagai media belajar merupakan solusi ketika terjadi kejenuhan atas metodologi pendidikan di dalam kelas.

Pendidikan sepatutnya menempatkan anak sebagai subyek karena setiap anak memiliki kebutuhan khusus dan unik sementara dunia anak adalah bermain untuk mengembangkan kreatifitasnya. Lingkungan alam sekitar adalah areal eksplorasi yang luas sekaligus media belajar yang tepat untuk mendidik anak mencintai lingkungan. Beragam metode pembelajaran untuk meningkatkan rasa cinta lingkungan seperti bercerita/mendongeng, merawat tanaman, petualangan individu, kegiatan cinta alam berbasis musik, puzzle bahan alam, laboratorium alam, demonstrasi, ceramah, diskusi, permainan alam terbuka (outbound), permainan kelompok, kerja kelompok atau kombinasi beberapa jenis metode tersebut. Dari semua jenis metode tersebut permainan yang dilakukan di alam terbuka (outbound) yang relatif sesuai diterapkan dalam mengembangkan pendidikan lingkungan hidup bagi anak usia dini karena permainan dapat meningkatkan spirit bersosial, kreativitas dan inspirasi bahkan ada yang dapat melatih anak untuk berpikir dengan bijaksana serta melatih kemampuan membuat rencana (al-Azizy, 2010). 
Bermain adalah hal yang sangat penting dalam dunia anak, sebab bermain sama halnya dengan bekerja bagi anak anak. Dunia anak adalah dunia bermain, dan belajar yang bersifat paling alami adalah dengan bermain. Anak - anak mendapat bermacam - macam pengetahuan dari bermain. Beberapa manfaat bermain adalah melatih fisik, kecerdasan dan ketangkasan otak. Dengan bermain, secara otomatis anak diberi kesempatan untuk menyelesaikan kesulitan dengan kemampuannya sendiri. Oleh karena itu implementasi dalam pembentukan karakter cinta lingkungan bagi anak usia dini sebagai tujuan pendidikan lingkungan hidup adalah dengan metode outbound (permainan di alam terbuka).

PEMBAHASAN

\section{Pendidikan Lingkungan Hidup}

Secara formal, pendidikan lingkungan menjadi alternatif yang rasional untuk memasukkan pendidikan lingkungan hidup ke dalam kurikulum. Hal ini ditegaskan dengan penandatanganan nota kesepahaman (MoU) antara Departemen Pendidikan Nasional (Depdiknas) dan kementrian Lingkungan Hidup (KLH) tahun 1996 yang direvisi pada bulan Juni 2005. Dengan penandatanganan $\mathrm{MoU}$ tersebut ada kekuatan yuridis sebagai landasan untuk menambah muatan kurikulum bagi siswa didik sejak usia dini pada pendidikan formal demi mencapai tujuan pendidikan lingkungan hidup dan implementasinya.

Pendidikan lingkungan hidup bagi anak usia dini dapat dimulai dengan berbagai kegiatan outbound berbasis cinta lingkungan. Pembiasaan perilaku cinta lingkungan membantu membentuk karakter anak didik. Perilaku cinta lingkungan merupakan sebuah aplikasi berupa tindakan untuk menjaga, merawat, dan melestarikan flora dan fauna termasuk pula tindakan mengelola seluruh kekayaan alam (tanah, air, dan udara) demi kelangsungan dan kesejahteraan hidup manusia.

Pendidikan lingkungan merupakan salah satu faktor penting dalam meraih keberhasilan dalam pengelolaan lingkungan hidup juga menjadi sarana yang sangat penting dalam menghasilkan sumber daya manusia yang dapat melaksanakan prinsip pembangunan berkelanjutan (Setina, 2014)

\section{Anak Usia Dini}

Anak usia dini adalah sosok individu yang sedang menjalani suatu proses perkembangan dengan pesat dan fundamental bagi kehidupan selanjutnya. Anak usia dini memiliki rasa ingin tahu dan sikap antusias terhadap segala sesuatu serta memliki minat yang kuat untuk berpetualang mengobservasi lingkungan. Pengenalan 
terhadap lingkungan di sekitarnya merupakan pengalaman yang positif untuk mengembangkan karakter keilmuan anak usia dini. Pengembangan sikap cinta lingkungan terhadap anak menimbulkan rasa memiliki terhadap alam yang ada disekitar dengan melakukan kegiatan menjaga dan melindungi kehidupan di alam sekitarnya agar tetap lestari.

Usia dibawah 5 tahun adalah usia yang paling kritis atau paling menentukan dalam pembentukan karakter dan kepribadian seseorang termasuk termasuk inteligensinya. Anak - anak selalu memiliki rasa ingin tahu yang luar biasa juga memiliki kemampuan yang tinggi menyerap informasi. Oleh karena itu, pendidikan yang menanamkan nilai - nilai luhur kemanusiaan (pengembangan intelegensia, karakter, kreativitas, moral dan kasih sayang) sangatlah perlu diberikan pada anak - anak sejak usia dini. Proses pembelajaran sebagai bentuk perlakuan yang diberikan pada anak harus memperhatikan karakteristik yang dimiliki setiap tahapan perkembangan anak.

Berdasarkan Undang - Undang Nomor 20 Tahun 2003 pasal 28 ayat 1 tentang Sistem Pendidikan Nasional berkaitan dengan Pendidikan Anak Usia Dini berbunyi :

Pendidikan Anak Usia Dini diselenggarakan bagi anak sejak lahir sampai dengan enam tahun dan bukan merupakan prasyarat untuk mengikuti pendidikan dasar

Selanjutnya pada Bab I pasal 1 ayat 14 ditegaskan bahwa,

Pendidikan Anak Usia Dini adalah suatu upaya pembinaan yang ditujukan kepada anak sejak lahir sampai dengan usia enam tahun yang dilakukan melalui pemberian rangsangan pendidikan untuk membantu pertumbuhan dan perkembangan jasmani dan rohani agar anak memiliki kesiapan dalam memasuki pendidikan lebih lanjut. Pendidikan Anak Usia Dini (PAUD) adalah suatu bentuk layanan pendidikan yang diberikan kepada anak sejak lahir hingga usia enam tahun dengan cara memberikan rangsangan terhadap seluruh aspek perkembangan yang dimiliki oleh anak meliputi aspek fisik dan non fisik (Yuliastia, $d k k, 2015$ ). Anak usia dini adalah anak yang termasuk dalam satuan Tempat Penitipan Anak (TPA), Kelompok Bermain dan Taman Kanak - kanak.

Pemberian stimulan terhadap anak sangat dipengaruhi oleh model pembelajaran yang diterapkan oleh guru. Untuk mencapai tujuan pendidikan lingkungan hidup pada tingkat Pendidikan Anak Usia Dini maka model pembelajaran luar kelas merupakan strategi pembelajaran yang relatif sesuai untuk diterapkan.

\section{Model Pembelajaran Luar Kelas}


Secara khusus istilah model diartikan sebagai kerangka konseptual yang digunakan sebagai pedoman dalam melakukan sesuatu kegiatan. Model pembelajaran adalah suatu kegiatan pembelajaran yang harus dikerjakan guru dan siswa agar tujuan pembelajaran dapat dicapai secara efektif dan efisien sehingga dalam model pembelajaran terkandung makna perencanaan. Artinya, bahwa model pembelajaran pada dasarnya masih bersifat konseptual tentang keputusan-keputusan yang akan di ambil dalam suatu pelaksanaan pembelajaran. Dengan kata lain model pembelajaran adalah kerangka konseptual yang melukiskan prosedur yang sistimatis dalam mengorganisasikan pengalaman belajar untuk mencapai tujuan belajar tertentu dan berfungsi sebagai pedoman bagi perancang pembelajaran dan para pengajar dalam merencanakan dan melaksanakan aktivitas pembelajaran.

Model pembelajaran luar kelas adalah kerangka konseptual tentang pembelajaran di luar kelas (outdoor study) sebagai pendekatan pembelajaran dalam meningkatkan pemahaman siswa karena siswa dapat merasakan pengalaman langsung melalui pengalaman sendiri di luar kelas terhadap suatu objek di lingkungan yang terdiri dari strategi, metode dan teknik pembelajaran yang bertujuan menciptakan metode pembelajaran aktif, kreatif dan inovatif untuk mengurangi rasa jenuh melalui kegiatan yang memadukan unsur bermain dan belajar dengan menggunakan alam sebagai media.

Dari sudut pandang kependidikan, aktivitas pendidikan yang dilakukan di luar lingkungan sekolah, setidaknya memuat tiga konsep utama yaitu konsep proses belajar, aktivitas luar kelas dan lingkungan.

Konsep proses belajar melalui aktivitas luar kelas (outdoor study) adalah proses belajar interdisipliner melalui satu seri aktivitas yang dirancang untuk dilakukan di luar kelas. Pendekatan ini secara sadar mengeksploitasi potensi latar alamiah untuk memberi kontribusi terhadap perkembangan fisik dan mental yang menggugah kesadaran terhadap hubungan timbal balik dengan lingkungan sehingga mampu mengubah sikap dan perilaku terhadap lingkungan yang mereka peroleh melalui pengalaman langsung di luar kelas.

Konsep aktivitas luar kelas merupakan suatu pendekatan dengan menggunakan kehidupan di luar ruangan yang memberikan banyak kesempatan bagi siswa untuk memperoleh dan menguasai berbagai bentuk keterampilan dasar, sikap 
dan apresiasi terhadap berbagai hal yang terdapat di luar kelas.

Konsep lingkungan yang merujuk pada eksplorasi ekologi sebagai andalan mahluk hidup yang saling tergantung satu sama lain. Lingkungan berperan penting sebagai sumber belajar yang memiliki tingkat variasi yang tinggi sehingga tepat dijadikan sebagai salah satu arena belajar yang dapat mempengaruhi peningkatan hasil belajar siswa pada suatu materi pembelajaran

Model pembelajaran luar kelas masih bersifat konseptual dan untuk mengimplementasikannnya digunakan salah satu metode pembelajaran luar kelas yaitu metode out bound (permainan di alam terbuka). Kegiatan permainan dan pembelajaran yang dilaksanakan di luar ruangan sebagai variasi metode/pendekatan yang digunakan dengan tujuan memperkenalkan lingkungan, melatih psikomotorik dan mengembangkan wawasan, pengetahuan, sikap dan prilaku anak didik PAUD (Budisetiawan,2011)

\section{Metode Out Bound}

Istilah outbound berasal dari kata outward bound. Outbound adalah sebuah ide pendidikan inovatif yang dikreasikan oleh Kurt Hahn. Kurt Hahn adalah seorang berkebangsaan Jerman yang lahir di Berlin pada tanggal 5 Juni 1886. Ide Kurt Hahn kini telah bertahan dan berkembang selama lebih dari enam puluh tahun (Kirana, 2012)

Outbound merupakan perpaduan antara permainan - permainan sederhana, permainan ketangkasan dan olahraga serta diisi dengan petualangan - petualangan yang pada akhirnya membentuk unsur ketangkasan dan kebersamaan serta keberanian dalam memecahkan masalah. Kirana (2012) menyatakan bahwa outbound adalah suatu program pembelajaran di alam terbuka (out door) berdasarkan pada prinsip experiential learning (belajar melalui pengalaman langsung) dengan melakukan beberapa simulasi permainan (outbound games) secara individu maupun per kelompok.

Metode out bound dipakai sebagai salah satu metode pengembangan karakter anak karena metode ini adalah sebuah simulasi kehidupan komplek menjadi sederhana dengan pendekatan melalui pengalaman penuh kegembiraan karena dilakukan dengan permainan. Anak langsung merasakan sukses atau gagal di dalam pelaksanaan sebuah tugas, karena anak terlibat langsung secara kognitif, afektif dan psikomotorik. Jadi, metode outbound merupakan suatu upaya proses belajar dan berlatih, yang bertujuan untuk 
menumbuhkan keterampilan tertentu pada anak usia dini.

Metode outbound sangat cocok untuk diterapkan dalam pembelajaran anak usia dini, karena outbound merupakan aktivitas/kegiatan permainan anak di ruang/alam terbuka yang sangat efektif dalam membangun pemahaman terhadap suatu konsep dan membangun prilaku dalam suasana rekreatif. Melalui metode outbound diharapkan anak lebih dekat dengan alam karena alam adalah sumber inspirasi dan ilmu pengetahuan bagi anak.

\section{Tujuan dan Karakteristik}

Tujuan dari kegiatan outbond ini adalah mampu menggali dan meningkatkan kemampuan yang dimiliki oleh anak melalui berbagai permainan yang menantang melalui media alam sehingga anak belajar mandiri dalam arti luas mulai dari mengatasi rasa takut, ketergantungan pada orang lain, belajar memimpin, mau mendengarkan orang lain, mau dipimpin dan belajar percaya diri. Renanda (2015) menyatakan bahwa tujuan metode outbound adalah memecah kebekuan (ice breaker), membangun kerjasama kelompok, membantu siswa untuk lebih bersemangat, membantu siswa untuk mampu memperbaiki teknik pengembangan diri, dan membantu siswa untuk mampu berpikir tentang cara menyelesaikan masalah dengan baik.

Budisetiawan (2011) menyatakan tujuan dari metode outbound adalah untuk mengatasi anak-anak yang mengalami kesulitan dalam hubungan sosial, meningkatkan konsep diri anak-anak, mengembangkan kemampuan dan gagasan kreatif, tertantang untuk berperan secara aktif dengan memberanikan diri, meningkatkan ketahanan fisik, serta meningkatkan kemampuan dan perilaku anak dalam kerjasama, kesetiakawanan dan kepemimpinan.

Kegiatan outbond sangat bermanfaat bagi siswa, sebab melalui outbond, siswa dapat menyegarkan kembali jasmani dan pikiran mereka setelah sehari-hari lelah belajar di sekolah. Selain itu, outbond juga merupakan media belajar sambil bermain yang membuat siswa dapat mengaplikasikan teori pembelajaran yang sudah dipelajari secara langsung terhadap alam. Ditambahkan pula oleh Wijayanti (2011) bahwa kegiatan outbound sangat penting dalam usaha memupuk kemandirian, keberanian, percaya diri, tanggung jawab, empati serta dapat memacu siswa untuk lebih kreatif dalam mengatasi permasalahan belajar di kelas. Di samping itu agar siswa dapat beradaptasi dengan lingkungan dan 
alam sekitar serta mengetahui pentingnya keterampilan hidup sehingga memperoleh pengalaman hidup di lingkungan alam sekitar dan pada akhirnya memiliki apresiasi terhadap lingkungan alam.

Metode outbound pada anak usia dini memiliki tujuan untuk mengembangkan 9 potensi kecerdasan (multi intelligence) anak, yaitu : Kecerdasan linguistik (linguistik intellegence), Kecerdasan logikamatematik (logico-mathematical intellegence), Kecerdasan visual-spasial (visual-spatial intellegence), Kecerdasan musikal (musical/rhythmic intellegence), Kecerdasan kinestetik (bodily/kinestetic intellegence), Kecerdasan naturalis (naturalist intellegnce), Kecerdasan interpersonal (Interpersonal intellegnce), Kecerdasan intrapersonal (intrapersonal intellegence), Kecerdasan spiritual (spiritual intellegence)

Salah satu ciri metode outbound adalah penuh dengan kegembiraan karena dilakukan dengan permainan, sehingga anak merasa senang di dalam kegiatan belajar. Melalui pengalaman belajar di alam terbuka ditemukan adanya keterangsangan minat belajar dan kegembiraan pada diri anak. Keterangsangan dan kegembiraan dalam bermain menyebabkan anak akan belajar dan memahami makna dari bermain tersebut.

\section{Prosedur Kerja}

Prosedur kerja dalam menyajikan pendidikan lingkungan hidup bagi anak usia dini dengan metode out bound meliputi : perencanaan, persiapan, pelaksanaan dan pembahasan, evaluasi dan tindak lanjut. Prosedur ini penting dilakukan agar penggunaan lingkungan sebagai sumber belajar berjalan efektif.

Perencanaan penyajian pendidikan lingkungan hidup dengan metode outbound bagi anak usia dini dilaksanakan dengan merumuskan strategi pembelajaran mencangkup tema, tujuan dan panitia pelaksana. Sebagaimana perencanaan pembelajaran kegiatan outbond di Sekolah Alam Bilingual SD Islam Surya Buana Malang diwujudkan dalam pembentukan panitia yang terdiri atas direktur, kepala sekolah, seluruh guru, dan orang tua siswa yang terbentuk dalam paguyuban kelas. Pelaksanaan outbond diwujudkan melalui pemberdayaan guru dan orang tua siswa sebagai fasilitator dan pengawas kegiatan. serta untuk pengevaluasiannya diwujudkan melalui pemberian tugas berupa pembuatan laporan oleh siswa tentang pengalaman kegiatan outbondnya yang berfungsi sebagai 
salah satu pertimbangan guru dalam pemberian nilai (Wijayanti, 2011)

Persiapan dilakukan dengan menentukan bentuk dan jenis kegiatan bertema lingkungan, menentukan waktu pelaksanaan kegiatan, menentukan area kegiatan, menyiapkan peralatan dan bahan yang diperlukan dan menempatkan fasilitator pendamping kelompok siswa.

Pada pelaksanaan kegiatan fasilitator utama/guru pendamping membagi siswa menjadi beberapa kelompok selanjutnya menjelasakan tentang materi yang akan diamati sekaligus menjelaskan aturan permainan dalam kegiatan outbound yang sudah dipersiapkan. Setelah kegiatan sudah dilaksanakan siswa diajak berdiskusi dengan memberi kesempatan berkomentar tentang kegiatan yang telah dilaksanakan sementara guru memfasilitasi dan menyisipkan makna permainan.

Evaluasi dilakukan setelah guru pendamping dan siswa membahas hasil kegiatan untuk menilai ketercapaian tujuan kegiatan dan mengukur tingkat keberhasilan siswa.

Dari hasil evaluasi dapat dirumuskan kembali strategi pembelajaran yang memuat rencana pembelajaran lanjutan pendidikan lingkungan hidup sebagai tindakan meningkatkan presentase keberhasilan proses belajar dengan mengalami langsung melalui interaksi di alam terbuka.

\section{Kegiatan Bertema Lingkungan Metode Outbound}

Beberapa kegiatan bertema lingkungan metode outbound bagai anak usia dini antara lain bercocok tanam, seni, demonstrasi, permainan benda mati dan benda hidup.

Kegiatan yang bisa dilakukan anak usia dini berupa kegiatan merawat tanaman berupa tanaman hias (Setina $d k k$, 2014). Tanaman hias merupakan media yang dapat digunakan dalam pembelajaran. Dengan pengenalan tersebut anak mengetahui berbagai jenis tanaman hias sehingga timbul rasa kecintaan akan tanaman. Hasil penelitian Setina $d k k$ (2014) menunjukkan terjadi peningkatan perilaku cinta lingkungan dengan kemampuan anak yang dikategorikan baik yaitu $80 \%$

Alam merupakan literatur yang penting untuk mengembangkan kemampuan anak, karena melalui penggunaan alam anak akan lebih mudah untuk memahami sehingga akan memberikan pesan moral kepada anak dalam mencintai lingkungan khususnya dalam mencintai tumbuh tumbuhan (Nurlaila, $d k k, 2014$ ). Respon anak terhadap lingkungan setelah memelihara tanaman di depan kelas dapat 
meningkatkan cinta lingkungan pada anak usia 5-6 tahun Taman Kanak-Kanak Rahadi Usman Ketapang antara lain: kepedulian anak menanam tanaman, kepedulian anak menjaga tanaman dengan memberikan pupuk, kepedulian anak menjaga tanaman dengan menyiram.

Kegiatan seni seperti menciptakan lagu bertema cinta lingkungan dan dinyanyikan oleh anak usia dini sebagaimana gagasan untuk mendorong produksi lagu bertema cinta lingkungan sehingga dapat dipergunakan bagi anak usia dini sebagai sarana edukasi cinta lingkungan. Dalam program outbound tersebut siswa secara aktif dilibatkan dalam seluruh kegiatan yang dilakukan. Dengan langsung terlibat pada aktivitas siswa akan segera mendapat umpan balik tentang dampak dari kegiatan yang dilakukan, sehingga dapat dimanfaatkan sebagai bahan pengembangan diri setiap siswa di masa mendatang yang melibatkan fisik, emosi, dan kecerdasan sehingga secara langsung mereka dapat lebih memahami diri sendiri dan orang lain. Kegiatan seni yang lain adalah opera sampah dimana siswa bermain peran dalam drama singkat dan spontan dalam bimbingan guru dengan tema berkisar tentang sampah dan bahayanya bagi kelangsungan hidup manusia.
Demonstrasi dapat dilakukan oleh guru atau fasilitator dengan memperagakan pembuatan bahan permainan dari limbah. Setelah peragaan siswa di dorong dan dibimbing untuk menciptakan bahan permainan yang lain sesuai minatnya. Kegiatan outbond ini dapat meningkatkan kemampuan daya cipta dan kemampuan motorik siswa. Sebagaimana hasil penelitian Yuliasti, $d k k$ (2015) pada anak kelompok B Semester II TK Negeri Negara Tahun Pelajaran 2014/2015 yang menyimpulkan bahwa kegiatan outbound melalui demonstrasi dapat meningkatkan kemampuan motorik kasar pada anak.

Permainan benda mati dan benda hidup dapat dipraktekkan pada anak usia dini untuk memperkenalkan jenis benda yang ada di lingkungan hidupnya. Pada awal permainan guru menjelaskan tentang pengertian dan contoh praktis benda hidup dan benda mati. Selanjutnya permainan dilakukan dengan membagi siswa menjadi 2 kelompok. Satu kelompok mengumpulkan aneka benda mati yang mereka temukan di area yang sudah ditentukan. Kelompok yang lain mengumpulkan aneka benda hidup yang mereka temukan di area yang sama. Setelah waktu yang diberikan habis maka masing masing kelompok memperlihatkan perolehan mereka dan secara bersama 
menghitung satu per satu. Kelompok yang memperoleh nilai yang tinggi adalah pemenangnya. Melalui permainan ini guru dapat menjelaskan tentang manfaat dan fungsi semua jenis benda di sekitar kita dan pentingnya keberadaan benda - benda tersebut bagi kehidupan manusia.

\section{Manfaat Metode Outbound}

Hasil penelitian Rinanda (2015) menunjukkan bahwa metode outbound berbentuk permainan kelompok, petualangan individu dan pemberian pesan dengan tujuan memecah kebekuan (ice breaker), membangun kerjasama kelompok, membantu siswa untuk lebih bersemangat, membantu siswa untuk mampu memperbaiki teknik pengembangan diri, dan membantu siswa untuk mampu berpikir tentang cara menyelesaikan masalah dengan baik.

Manfaat outbound yang dirasakan siswa adalah mampu melahirkan kompetisi yang sehat dan membangun rasa percaya diri yang kuat (Rinanda, 2015). Melalui permainan outbond sains akan terbangun suasana yang lepas, bebas, menyenangkan dan atraktif serta memberi makna dalam belajar siswa (Andi, 2010)

Melalui pelatihan outbound, diharapkan lahir pribadi - pribadi baru yang penuh motivasi, berani, percaya diri, berpikir kreatif, memiliki rasa kebersamaan, tanggung jawab, kooperatif, rasa percaya diri, berkarakter dan toleransi (Dananjaya, 2013)

\section{Kelebihan dan Kekurangan Metode Outbound}

Kelebihan metode outbound antara lain adalah membuat proses pembelajaran berpusat pada siswa yang memungkinkan siswa berkembang sebagai individu yang dapat berfungsi secara menyeluruh, memungkinkan siswa membentuk self concept sehingga siswa dapat mengenal dirinya sendiri dengan lebih baik, yaitu mengenal kelebihan dan kekurangan dirinya melatih siswa untuk mengkonstruksi konsep dari pengalaman-pengalamannya yang menyenangkan, mengembangkan bakatbakat siswa, mencegah siswa belajar hanya pada tingkat verbal saja. Belajar sambil bermain memberi waktu kepada siswa untuk mengasimilasi dan mengakomodasi informasi yang diperoleh melalui inderanya. Selain itu melalui permainan di alam terbuka "memaksa" siswa memberikan respon spontan yang melibatkan fisik, emosi, dan kecerdasan sehingga secara langsung mereka dapat lebih memahami diri sendiri dan orang lain.

Disamping itu kelebihan dari metode ini adalah memotivasi semangat belajar siswa karena menggunakan setting 
alam terbuka sebagai sarana kelas yang mendukung keseluruhan proses pembelajaran, menimbulkan rasa senang dan gembira selama proses pembelajaran, di pihak lain guru dapat membangun suasana belajar sambil bermain dan bebas bereksplorasi, siswa dapat menggunakan media belajar yang konkrit dan memahami lingkungan sekitarnya, mengasah aktivitas fisik dan kreatifitas siswa karena tuntutan strategi pembelajaran sambil melakukan.

\section{Sedangkan kekurangan metode} outbound antara lain waktu yang digunakan relatif lama, membutuhkan peralatan dan sumber belajar yang beragam, tenaga yang dibutuhkan lebih banyak, ide permainan dan memberi makna pada tiap konsep memerlukan kreativitas dan perhatian yang lebih dari guru. Di samping itu kegiatan outbound memerlukan perhatian ekstra guru/fasilitator saat pembelajaran karena menggunakan media sesuai dengan kenyataan yang memberi peluang bagi anak bermain melampaui batas waktu

\section{KESIMPULAN}

Pendidikan Lingkungan Hidup pada Anak Usia Dini dapat disajikan dengan strategi pembelajaran yang menggunakan metode outbound untuk mencapai tujuan pembelajaran. Dengan prosedur pelaksanaan yang disusun secara sistimatis diharapkan dapat berkontribusi dalam pembentukan karakter cinta lingkungan anak usia dini.

\section{DAFTAR PUSTAKA}

Al-Azizy, AS.2010. Ragam latihan Khusus Asah Ketajaman Otak Anak Melejitkan Daya Ingatnya. Jogjakarta: DIVA Press (Anggota IKAPI)

Andi, 2010. Pembelajaran Inovatif Pemanfaatan Outbound Sains Sebagai Sarana Mewujudkan Meaningful Learning melalui....diakses....Mei 2016

Budisetiawan.2011. Bahan Belajar Pelatihan Pelatih (TOT) Outbound Anak Usia Dini Bagi Pendidik PAUD melalui http://budisetiawanbudisetiawan.blogspot.com posting 10 Oktober 2011 diakses 10 Mei 2016

Dananjaya, U.2013. Media Pembelajaran Aktif. Bandung: Nuansa Cendikia, hal.15

Fatmawati, Ni'mah. 2013. Meningkatkan Kecerdasan Interpersonal Anak Melalui Kegiatan Outbound di TK Pertiwi 1 Suwatu Taman Sragen Tahu Pelajaran 2012/2013 (Skripsi). Surakarta : Pendidikan Anak Usia Dini (PAUD) Fakuktas Keguruan dan Ilmu Pendidikan Universitas Muhamadiyah.

http://digilib.uinsby.ac.id. Kajian Teori Outbound. Diakses 13 Mei 2016

Kirana Adventure. 2012. Pengertian, Sejarah, Manfaat dan Tujuan Outbound melalui www.kiranagroup.com by Go 
Outbound on Desember 16, 2012, posted in : outbound diakses $13 \mathrm{Mei}$ 2016

Nurlaila, Fadillah, Busri Endang,....Sikap Cinta Lingkungan Pada Anak usia 5 - 6 tahun di Taman Kanak - Kanak Rahadi Usman

Rinanda, Alriza Ayu. 2015. Outbound Sebagai Upaya Meningkatkan Motivasi Belajar Siswa Kelas IX Tahun Ajaran 2014/2015 SMP Muhammadiyah 3 Depok (Skripsi). Jogyakarta : Universitas Islam Negeri Sunan Kalijaga. Fakultas Dakwah dan Komunikasi

Setina, Marmawi, R.M. Thamrin. 2014. Peningkatan Perilaku Cinta Lingkungan Pada Usia 5-6 tahun Melawi. Program Studi Pendidikan Guru pendidikan Anak Usia Dini. Pontianak : FKIP UNTAN

Sholeh, M. 2012. Konsep Dasar Outdoor Study. melalui musholeh.blogspot.co.id

Tsaqqofa, Sarah, Ahmad FP, Yoga Prasetyo, 2011. Poni dan Tonga: Model Pendidikan Karakter Cinta Lingkungan Berbasis Musik (Music Based Learning) Pada Anak Usia Dini ( 3 - 6 tahun). Bogor: (Program Kegiatan Mahasiswa) IPB
Widyawati, Susiana. 2012. Upaya Meningkatkan Kemandirian Melalui Kegiatan Outbound Pada Anak Usia Dini Kelompok Bermain Pelangi Ceria Jirapan Masaran Sragen TAHUN 2011/2012 (Skripsi). Surakarta : Pendidikan Anak Usia Dini FKIP Universitas Muhammadiyah.

Wijayanti, Della Olivia. 2011. Manajemen Pembelajaran Outbound di Sekolah Alam (Studi Kasus Sekolah Alam Bilingual SD Islam Surya Buana Malang). Skripsi. Malang: Jurusan Administrsi Pendidikan, Fakultas Ilmu Pendidikan Universitas Negeri

Yuliarto, H, dkk. Fatkurahman Arjuna, M.Or. E-Mail: Arjuna@yahoo.com

Yuliastia, IAR, Nyoman Jampel, Mutiara Magta. 2015. Penerapan Metode

Demontrasi Melalui Kegiatan Outbound Untuk Meningkatkan Kemampuan Motorik Kasar Anak Kelompok B semester II.... TK Negeri Negara Tahun Pelajaran 2014-2015. e-Journal Pendidikan Guru PAUD UNIVERSITAS Pendidikan Ganesha Jurusan Pendidikan Guru PAUD (Volume 3 No : 1 - tahun 2015) 